\title{
Clinical significance of interleukin-6 (IL-6) in the spread of gastric cancer: role of IL-6 as a prognostic factor
}

\author{
Tatsuto Ashizawa ${ }^{1}$, Ryosuke Okada ${ }^{1}$, Yoshiaki Suzuki ${ }^{1}$, Makoto Takagi ${ }^{1}$, Tatsuyuki Yamazaki ${ }^{1}$, \\ Tetsuo Sumi ${ }^{1}$, Toshiaki Aoki ${ }^{1}$, Shinobu Ohnuma ${ }^{2}$, and Tatsuya Aoki ${ }^{2}$ \\ ${ }^{1}$ Department of Digestive Tract Surgery, Hachioji Medical Center of Tokyo Medical University, Tate-machi, Hachioji, Tokyo 193-0998, \\ Japan \\ ${ }^{2}$ Department of Surgery, Tokyo Medical University, Tokyo, Japan
}

\begin{abstract}
Background. It is becoming clear that various cytokines are associated with the spread of cancer cells. The purpose of this study was to compare interleukin (IL)-6 levels in patients with gastric cancer to elucidate the role of IL-6 in predicting the spread of tumors.

Methods. In 60 patients, we assessed the correlation of serum IL-6 (pg/ml) with stage, histological findings, hepatic metastasis, and related factors (hepatocyte growth factor [HGF], IL$1 \beta$, tumor necrosis factor [TNF]- $\alpha$, and transforming growth factor [TGF]-ק1). We also investigated the diagnostic significance of the IL-6 level for advanced gastric cancer and lymph node metastasis, as well as the association between IL-6 elevation and outcome. Finally, we examined the expression of IL-6 in tumor tissue.

Results. Significant relationships were seen between serum IL-6 and stage, depth of tumor invasion (pT), lymphatic invasion (ly), venons invasion (v)*, lymph node metastasis $(\mathrm{pN})$, hepatic metastasis $(\mathrm{cH})$, and HGF $(P<0.01 ; * P<0.05)$. With regard to the diagnostic significance of the IL-6 level for advanced gastric cancer and lymph node metastasis, when the cutoff value of IL-6 was set at $1.97 \mathrm{pg} / \mathrm{ml}$, the sensitivity was $81.8 \%$ and $87.5 \%$; specificity was $66.7 \%$ and $58.3 \%$; and accuracy was $77.1 \%$ and $72.9 \%$, respectively. The 1 - and 3-year cumulative survival rates for patients with an IL-6 value of more than $1.97 \mathrm{pg} / \mathrm{ml}(69.0 \%$ and $43.4 \%$, respectively) were significantly lower than those for patients with an IL-6 value of $1.97 \mathrm{pg} / \mathrm{ml}$ or less $(94.4 \%$ and $87.2 \%$, respectively; $\boldsymbol{P}<$ 0.05). Immunohistochemical staining was positive for IL-6 in the cytoplasm of cancer cells.

Conclusion. We suspect that IL-6 is involved in cancer invasion and lymph node and/or hepatic metastasis. Our results indicate that IL-6 could be used as a prognostic factor for survival.
\end{abstract}

Key words IL-6 · HGF · Advanced gastric cancer · Lymph node metastasis · Hepatic metastasis - Outcome $\cdot$ Prognostic factor

Offprint requests to: $\mathrm{T}$. Ashizawa

Received: July 5, 2004 / Accepted: January 11, 2005
Introduction

A cancer cell has the ability to invade host stroma and to metastasize. Metastasis refers to the ability of cancer cells to invade the stroma and to generate secondary tumors at sites distant from the primary tumor. It is well known that the spread of tumors can be enhanced not only by cancer cells but also by interstitial cells. It is becoming clear that various cytokines, produced by cancer tissues, including interstitial cells, are associated with invasion and metastasis [1,2]. Cytokines are considered to form a cytokine network, either autocrine or paracrine, and to be involved in the system of invasion and metastasis through receptors expressed on cancer cells.

The purpose of this study was to compare the serum levels of IL-6 in patients with gastric cancer to elucidate the possible role of IL-6 in predicting the spread of tumors in relation to the grade of histological findings (depth of tumor invasion [pT], lymphatic invasion [ly], venous invasion $[\mathrm{v}]$, and lymph node metastasis $[\mathrm{pN}]$ ) and hepatic metastasis $(\mathrm{cH})$. We also examined the role of IL-6 as a prognostic factor and its diagnostic significance for advanced gastric cancer and lymph node metastasis.

\section{Patients and methods}

\section{Patients}

Sixty patients with gastric cancer diagnosed histopathologically, without pre-treatment, who underwent gastrectomy at our department between January 1998 and March 2003 were enrolled in this study. The patients consisted of 43 men and 17 women (mean age, 64.1 years; range, $40-83$ years). Twenty healthy volunteers were also analyzed as controls. Twelve patients were considered to have hepatic metastasis clinically. In the 
remaining 48 patients, the depth of tumor invasion was pT1 in 15 patients, pT2 in 16, pT3 in 15, and pT4 in 2; lymphatic invasion was ly0 in 16 patients, ly1 in 15 , ly 2 in 8 , and ly3 in 9; venous invasion was v0 in 18 patients, v1 in 12 , v2 in 12, and v3 in 6; and lymph node metastasis was pN0 in 24 patients, pN1 in 13, pN2 in 7, and pN3 in 4 . There were 21 patients with stage I disease, 9 with stage II, 13 with stage III, and 17 with stage IV (Table 1).

\section{Methods}

In the 60 patients with gastric cancer, we statistically assessed the correlation of preoperative serum levels of IL-6 ( $\mathrm{pg} / \mathrm{ml})$ with the stage, the grade of histological findings ( $\mathrm{pT}, \mathrm{ly}, \mathrm{v}, \mathrm{pN})$, hepatic metastasis ( $\mathrm{cH})$, and IL6 related cytokines (hepatocyte growth factor [HGF; $\mathrm{ng} / \mathrm{ml}$ ], IL-1 $\beta(\mathrm{pg} / \mathrm{ml})$, tumor necrosis factor- $\alpha$ [TNF- $\alpha$; $\mathrm{pg} / \mathrm{ml}$, and transforming growth factor- $\beta 1$ [TGF- $\beta 1$; $\mathrm{ng} / \mathrm{ml}])$.

We determined the diagnostic significance of IL-6 for advanced gastric cancer and lymph node metastasis.

Table 1. Patients' characteristics

\begin{tabular}{|c|c|}
\hline Number of patients & 60 \\
\hline \multicolumn{2}{|l|}{ Age (years) } \\
\hline Median & 64.1 \\
\hline Range & $40-83$ \\
\hline \multicolumn{2}{|l|}{$\operatorname{Sex}(\%)$} \\
\hline Male & $43(71.7)$ \\
\hline Female & $17(28.3)$ \\
\hline \multicolumn{2}{|c|}{ Hepatic metastasis $(\mathrm{cH}), n(\%)$} \\
\hline 1 & $12(20.0)$ \\
\hline 0 & $48(80.0)$ \\
\hline \multicolumn{2}{|c|}{ Depth of tumor invasion ( $\mathrm{pT}), n(\%)$} \\
\hline 1 & $15(31.3)$ \\
\hline 2 & $16(33.3)$ \\
\hline 3 & $15(31.3)$ \\
\hline 4 & $2(4.1)$ \\
\hline \multicolumn{2}{|c|}{ Lymphatic invasion (ly), $n$ (\%) } \\
\hline 0 & $16(33.3)$ \\
\hline 1 & $15(31.3)$ \\
\hline 2 & $8(16.7)$ \\
\hline 3 & $9(18.7)$ \\
\hline \multicolumn{2}{|c|}{ Venous invasion $(\mathrm{v}), n(\%)$} \\
\hline 0 & $18(37.5)$ \\
\hline 1 & $12(25.0)$ \\
\hline 2 & $12(25.0)$ \\
\hline 3 & $6(12.5)$ \\
\hline \multicolumn{2}{|c|}{ Lymph node metastasis $(\mathrm{pN}), n(\%)$} \\
\hline 0 & $24(50.0)$ \\
\hline 1 & $13(27.1)$ \\
\hline 2 & 7 (14.6) \\
\hline 3 & $4(8.3)$ \\
\hline \multicolumn{2}{|l|}{ Stage, $n(\%)$} \\
\hline I & $21(35.0)$ \\
\hline II & $9(15.0)$ \\
\hline III & $13(21.7)$ \\
\hline IV & $17(28.3)$ \\
\hline
\end{tabular}

We studied the association between IL-6 elevation and outcome, and compared IL-6 and clinicopathological prognostic factors $(\mathrm{pT}, \mathrm{ly}, \mathrm{v}, \mathrm{pN}, \mathrm{cH})$ with regard to outcome. We also examined the expression of IL-6 in tumor tissue by immunohistochemical staining, using an anti-human IL-6 monoclonal antibody (Cosmo Bio, Tokyo, Japan). Histological findings were described according to the Japanese classification of gastric carcinoma, 13 th edition [3].

\section{Assay of serum cytokine values}

The serum level of IL-6 was measured by chemiluminescent enzyme immunoassay (CLEIA), using a commercial kit (Fujirebio, Tokyo, Japan). The serum values of other cytokines were measured by enzyme-linked immunosorbent assays (ELISAs), by means of commercially available methods: HGF (Otsuka Pharmaceutical, Tokyo, Japan), IL-1 $\beta$ (Biosource Europa, Camarillo, CA, USA), TNF- $\alpha$ (Japan Immunoresearch Laboratories, Gunma, Japan), and TGF- $\beta 1$ (R\&D System, Minneapolis, MN, USA).

\section{Statistical analysis}

Spearman's rank correlation coefficient $(r s)$ was used to assess the correlation of IL-6 with stage, histological findings, hepatic metastasis, and IL-6 related cytokines. The comparison of IL-6 in relation to the stage and histological variables was assessed by the KruskalWallis $H$-test and Mann-Whitney $U$-test with Bonferroni correction. Comparisons of IL-6 in regard to $\mathrm{cH}$ were assessed by unpaired $t$-test. Survival curves for patients were plotted using the Kaplan-Meier method, and differences were assessed by the log-rank test and the generalized Wilcoxon test. A $P$ value of less than 0.05 was considered to indicate a statistically significant difference. IL-6 and clinicopathological prognostic factors were compared with regard to survival using Cox proportional analysis.

\section{Results \\ Correlation of IL-6 values with disease stage}

A significant relationship was seen between IL-6 and the four disease stages $(r \mathrm{~s}=0.67018 ; P<0.01)$. The mean IL-6 values in stage I $(2.14 \pm 1.57 \mathrm{pg} / \mathrm{ml})$ and stage IV $(11.77 \pm 10.58 \mathrm{pg} / \mathrm{ml})$ patients were statistically significantly higher than those in healthy volunteers $(1.05 \pm 0.46 \mathrm{pg} / \mathrm{ml} ; H=52.292 ; P<0.01)$. However, there was no significant difference in IL-6 values among stage I, stage II $(4.97 \pm 2.52 \mathrm{pg} / \mathrm{ml})$, stage III $(5.19 \pm$ $3.38 \mathrm{pg} / \mathrm{ml}$ ), and stage IV patients (Fig. 1). 


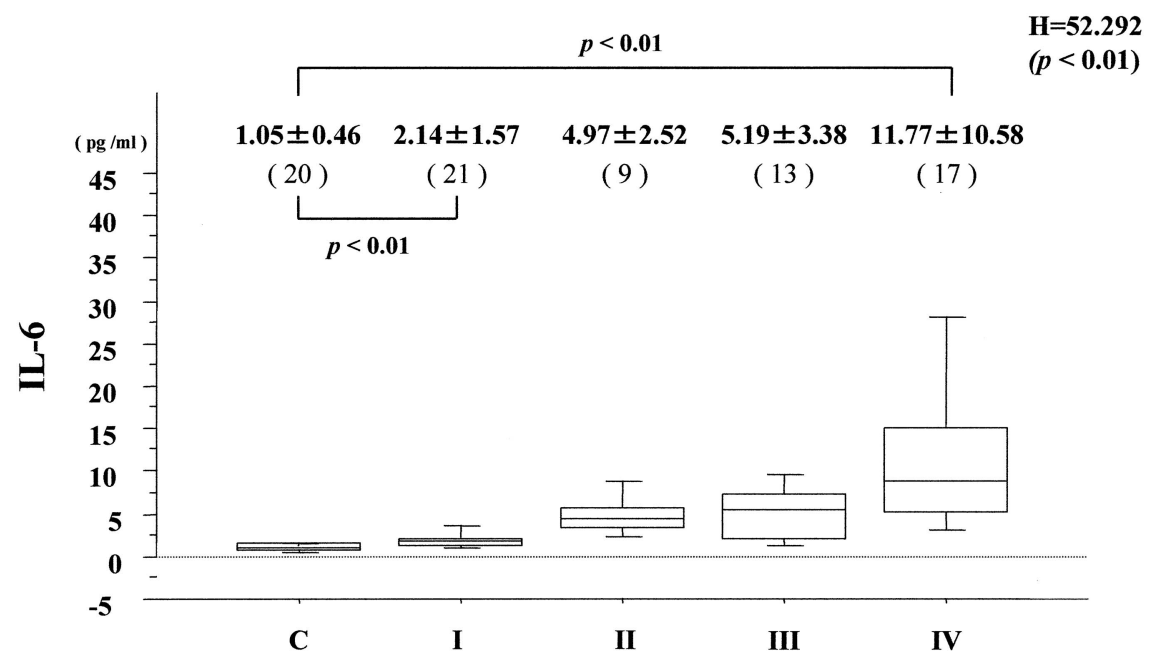

Fig. 1. Comparison of serum interleukin$6(I L-6)$ values in control subjects $(C)$ and patients according to disease stage. Numbers in parentheses are numbers of patients

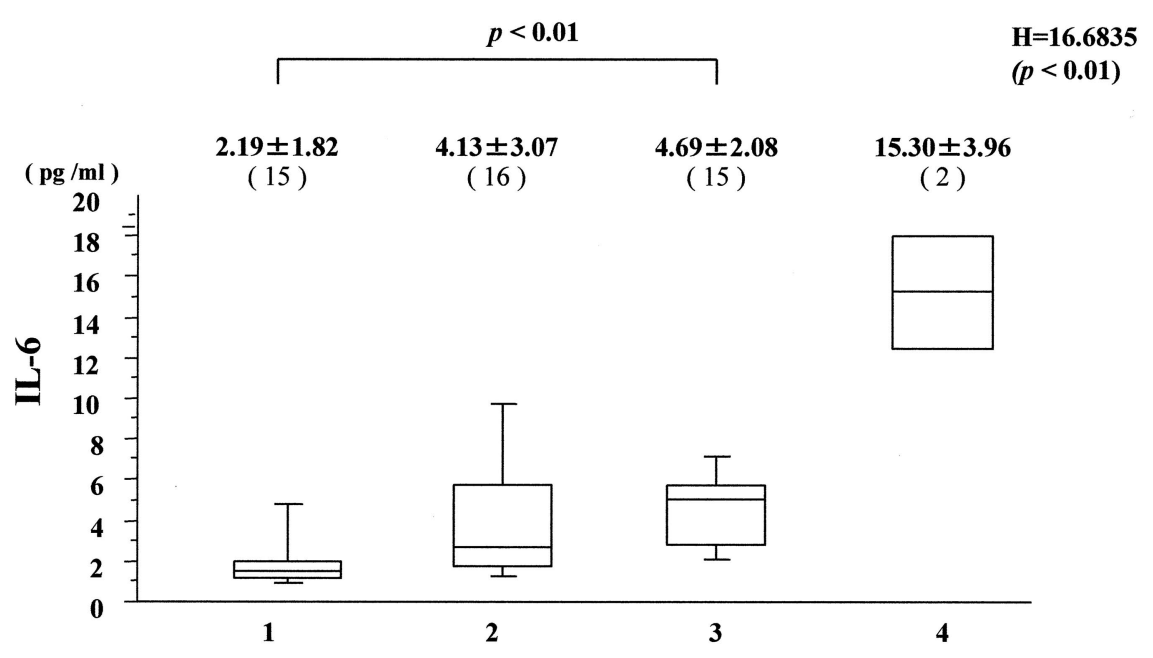

Fig. 2. Comparison of serum IL-6 values in patients according to depth of tumor invasion (numbers on horizontal axis). Numbers in parentheses are numbers of patients

\section{Correlation of IL-6 values with grade of} histological findings

Depth of tumor invasion ( $p T$ )

A significant relationship was seen between IL-6 and the four grades of $\mathrm{pT}(r \mathrm{~s}=0.5778 ; P<0.01)$. The mean IL-6 value was statistically significantly higher in pT3 patients $(4.69 \pm 2.08 \mathrm{pg} / \mathrm{ml})$ than in $\mathrm{pT} 1$ patients $(2.19 \pm$ $1.82 \mathrm{pg} / \mathrm{ml} ; H=16.6835 ; P<0.01)$. However, there was no significant difference in IL-6 values among pT1, pT2 $(4.13 \pm 3.07 \mathrm{pg} / \mathrm{ml}), \mathrm{pT} 3$, and pT4 $(15.3 \pm 3.96 \mathrm{pg} / \mathrm{ml})$ patients, except for pT1 vs pT3 (Fig. 2).

\section{Lymphatic invasion (ly)}

A significant relationship was seen between IL-6 and the four grades of ly $(r \mathrm{~s}=0.49851 ; P<0.01)$. The mean
IL-6 value was statistically significantly higher in ly2 patients $(4.65 \pm 1.73 \mathrm{pg} / \mathrm{ml})$ than in ly0 patients $(2.31 \pm$ $1.80 \mathrm{pg} / \mathrm{ml} ; H=11.8992 ; P<0.05)$. However, there was no significant difference in IL-6 values among ly0, ly1 $(4.51 \pm 3.91 \mathrm{pg} / \mathrm{ml}), \mathrm{ly} 2$, and $\mathrm{ly} 3(6.44 \pm 4.84 \mathrm{pg} / \mathrm{ml})$ patients, except for ly0 vs ly2 (Fig. 3).

Venous invasion (v)

A significant relationship was seen between IL-6 and the four grades of $\mathrm{v}(r \mathrm{~s}=0.36304 ; P<0.05)$. The mean IL-6 value was statistically significantly higher in v2 patients $(7.05 \pm 4.55 \mathrm{pg} / \mathrm{ml})$ than in v0 patients $(2.79 \pm$ $2.59 \mathrm{pg} / \mathrm{ml} ; H=11.9274 ; P<0.05)$. However, there was no significant difference in IL-6 values among v0, v1 $(3.70 \pm 2.46 \mathrm{pg} / \mathrm{ml}), \mathrm{v} 2$, and $\mathrm{v} 3$ patients $(3.43 \pm 2.35 \mathrm{pg} /$ $\mathrm{ml}$ ), except for v0 vs v2 (Fig. 4). 


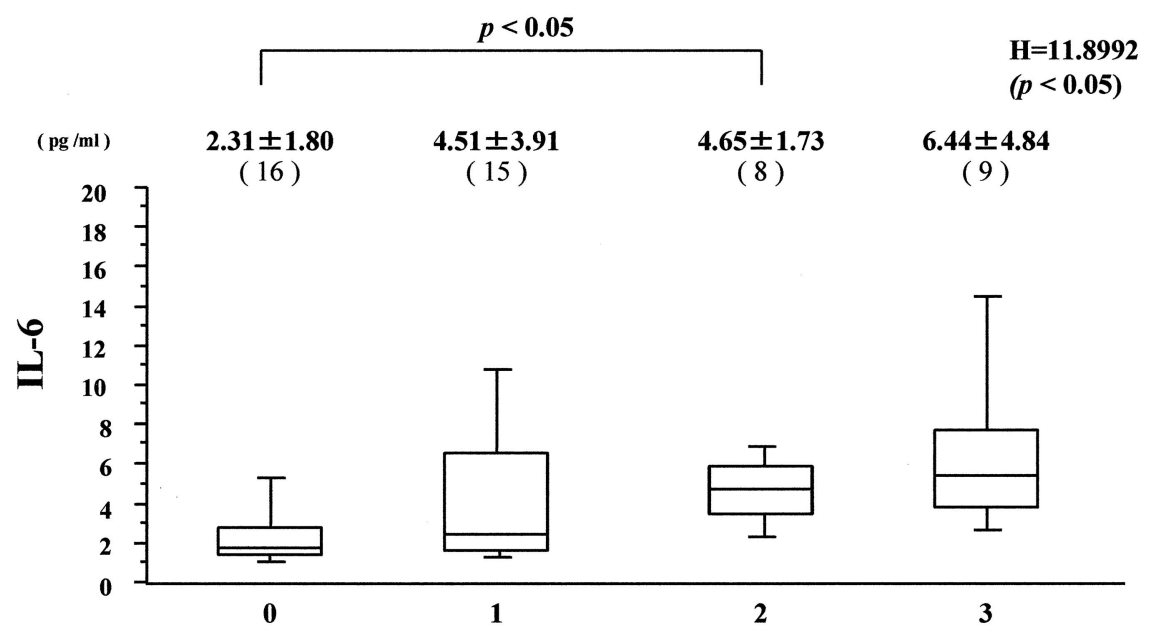

Fig. 3. Comparison of serum IL-6 values according to lymphatic invasion (numbers on horizontal axis). Numbers in parentheses are numbers of patients

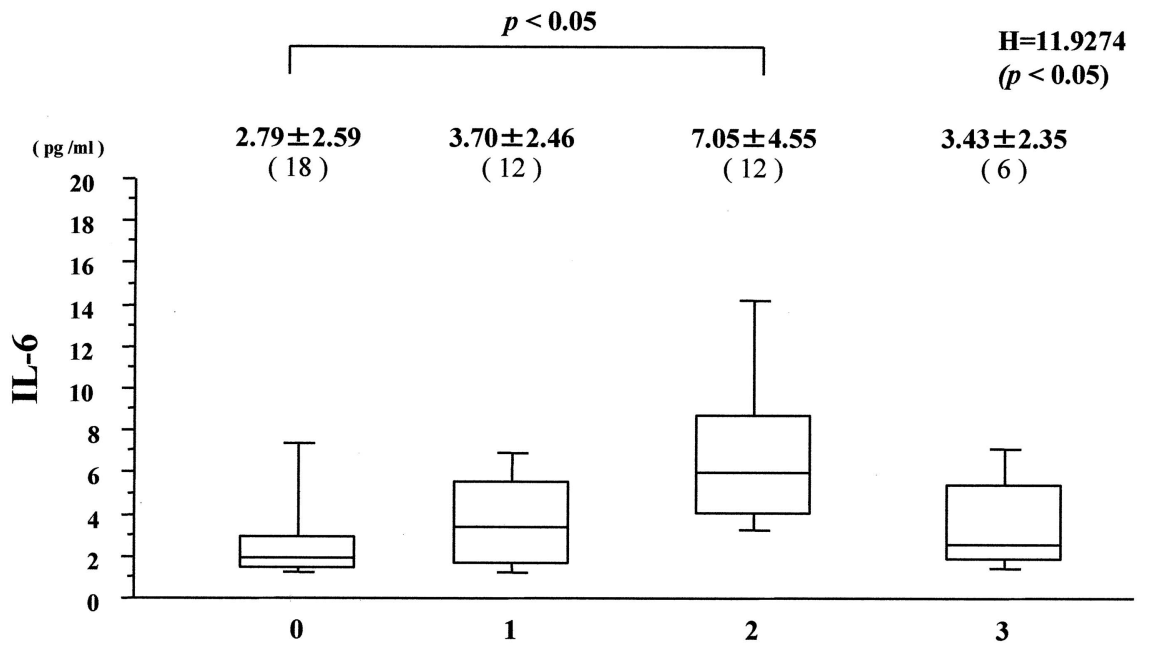

Fig. 4. Comparison of serum IL-6 values according to venous invasion (numbers on horizontal axis). Numbers in parentheses are numbers of patients
Lymph node metastasis ( $p N)$

A significant relationship was seen between IL-6 and the four grades of $\mathrm{pN}(r \mathrm{~s}=0.55876 ; P<0.01)$. The mean IL-6 value was significantly higher in pN1 patients $(5.48 \pm 3.32 \mathrm{pg} / \mathrm{ml})$ than in $\mathrm{pN} 0$ patients $(2.35 \pm 1.61 \mathrm{pg} / \mathrm{ml} ; H=16.0375 ; P<0.01)$. However, there was no significant difference in IL-6 values among $\mathrm{pN} 0, \mathrm{pN} 1, \mathrm{pN} 2(6.77 \pm 5.69 \mathrm{pg} / \mathrm{ml})$, and $\mathrm{pN} 3$ patients $(6.15 \pm 2.81 \mathrm{pg} / \mathrm{ml})$, except for $\mathrm{pN} 0 \mathrm{vs} \mathrm{pN} 1$ (Fig. 5).

\section{Correlation of IL-6 with hepatic metastasis $(\mathrm{cH})$}

The mean IL-6 value was significantly higher in cH1 patients $(13.12 \pm 11.99 \mathrm{pg} / \mathrm{ml})$ than in $\mathrm{cH} 0$ patients $(4.16$ $\pm 3.50 \mathrm{pg} / \mathrm{ml} ; P<0.0001)$; thus, a significant relationship was seen between IL-6 value and hepatic metastasis $(r \mathrm{~s}=0.44149 ; P<0.01$; Fig. 6$)$.
Correlation of IL-6 with related cytokines

A significant relationship was seen between IL-6 and HGF ( $r \mathrm{~s}=0.43527 ; P<0.01)$. However, there was no significant relationship between IL-6 and IL-1 $\beta$ ( $r \mathrm{~s}=$ 0.21125 ; not significant [NS]), TNF- $\alpha$ ( $r$ s not calculated; $\mathrm{NS})$, or TGF- $\beta 1$ ( $r \mathrm{~s}=0.26446$; NS).

Diagnostic significance of IL-6 for advanced gastric cancer and lymph node metastasis

When the cutoff value of IL-6 was set at $1.97 \mathrm{pg} / \mathrm{ml}$ (mean + 2SD for 20 healthy volunteers), with regard to diagnostic significance for advanced gastric cancer (pT2, pT3, and pT4 patients), the sensitivity was $81.8 \%$ (27/33); specificity, 66.7\% (10/15); positive predictive value, $84.4 \%$ (27/32); negative predictive value, $62.5 \%$ (10/16); and accuracy, $77.1 \%$ (37/48). With regard to 


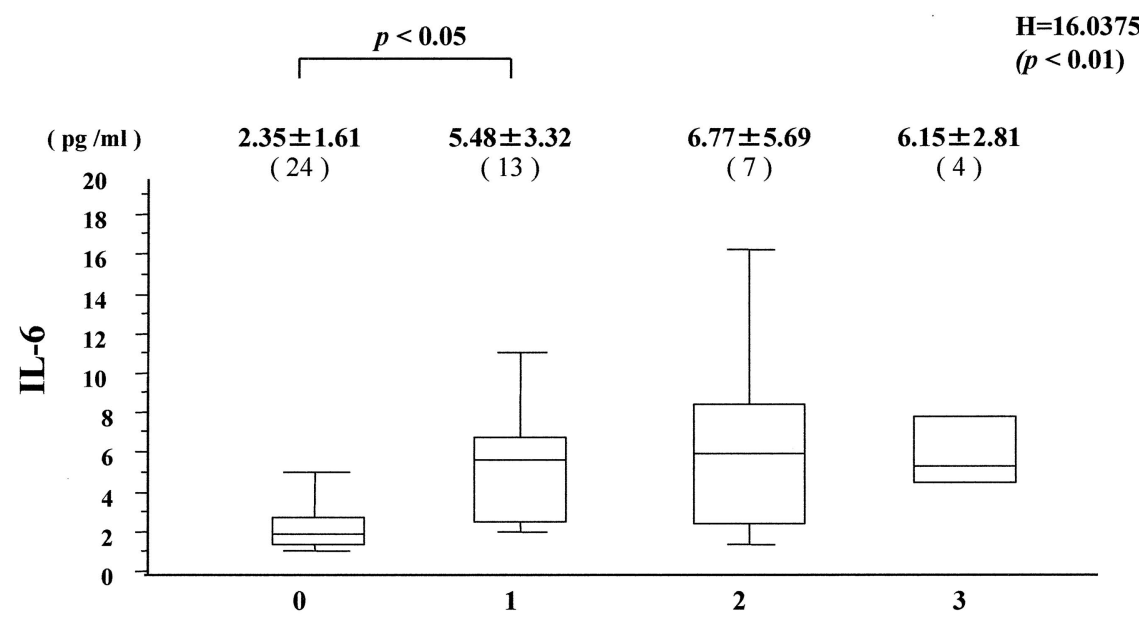

Fig. 5. Comparison of serum IL-6 values according to lymph node metastasis (numbers on horizontal axis). Numbers in parentheses are numbers of patients

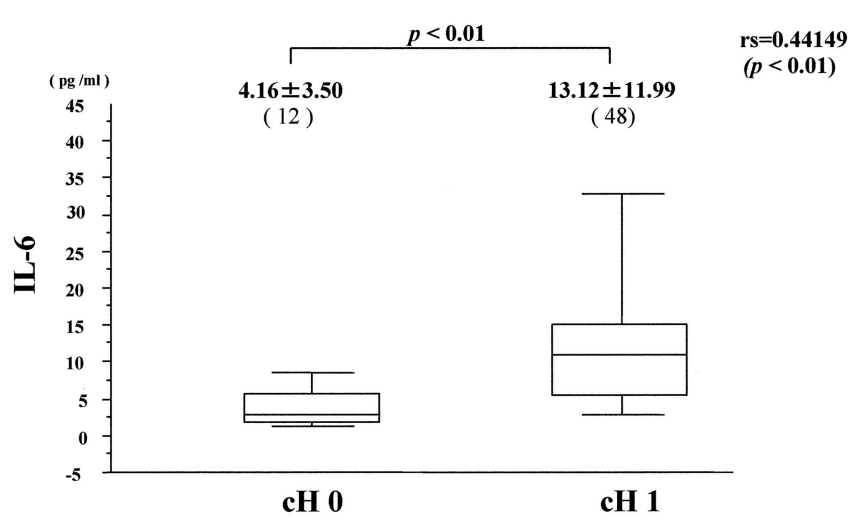

Fig. 6. Comparison of serum IL-6 values according to hepatic metastasis $(\mathrm{cH})$. Numbers in parentheses are numbers of patients

diagnostic significance for lymph node metastasis (pN1, $\mathrm{pN} 2$, and $\mathrm{pN} 3$ patients), the sensitivity was $87.5 \%$ (21/ 24); specificity, $58.3 \%$ (14/24); positive predictive value, 67.7\% (21/31); negative predictive value, $82.4 \%$ (14/17); and accuracy, $72.9 \%(35 / 48)$.

\section{Outcomes}

Analysis of survival was conducted in 60 patients. We assessed the correlation between the serum levels of IL6 and outcome (survival time). Patients were divided into two groups based on the IL-6 cutoff value $(1.97 \mathrm{pg} /$ $\mathrm{ml}$ ). The high-level group (43 patients) represented the population with levels higher than the cutoff value and the low-level group (17 patients) represented the population with levels equal to or lower than the cutoff value. The distribution of survival time was compared between the two groups. The 1- and 3-year cumulative survival rates for patients with an IL-6 value of more than $1.97 \mathrm{pg} / \mathrm{ml}(69.0 \%$ and $43.4 \%)$ were significantly lower than those for patients with an IL-6 value of $1.97 \mathrm{pg} / \mathrm{ml}$ or less $(94.4 \%$ and $87.2 \%)$ as assessed by the log-rank test $(P<0.05)$ and the generalized Wilcoxon test $(P<0.05$; Fig. 7$)$.

The Cox proportional hazards model was applied to multivariate analysis to test the relationship of regression parameters with outcome. When the six variables (i.e., IL-6, pT, ly, v, pN, and $\mathrm{cH}$ ) were applied to the model, IL-6 $(P=0.0276)$ was inferior to $\mathrm{pN}(P=$ $0.0089)$ as a prognostic factor, but it had a relatively stronger correlation with the survival rate than $\mathrm{pT}(P=$ $0.1849)$, ly $(P=0.2256), \mathrm{v}(P=0.2427)$, and $\mathrm{cH}(P=$ 0.0989).

\section{Immunohistochemical staining}

In all four patients with very high serum levels of IL-6 (more than $15.0 \mathrm{pg} / \mathrm{ml}$ ), immunohistochemical staining showed positive findings for IL-6 in the cytoplasm of cancer cells. On the other hand, there was no evidence of positive findings for IL- 6 in five patients with low serum levels of IL-6 (less than $1.5 \mathrm{pg} / \mathrm{ml}$ ).

\section{Case example}

We report representative findings in an a 83-year-oldwoman who suffered from gastric cancer and presented with a high temperature $\left(37.5^{\circ} \mathrm{C}-38.5^{\circ} \mathrm{C}\right)$. Although laboratory data showed elevations of the white blood

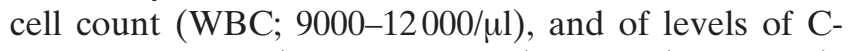
reactive protein (CRP; 6-8 mg/dl), HGF $(1.58 \mathrm{ng} / \mathrm{ml})$, and IL-6 $(30.5 \mathrm{pg} / \mathrm{ml})$, no evidence of an inflammatory focus was observed upon further clinical examination. After distal gastrectomy and lymph node dissection, a reduction of the temperature and a decrease of $\mathrm{WBC}$, CRP, HGF, and IL-6 occurred. The resected specimen revealed poorly differentiated adenocarcinoma (Fig. 8A) (por2, pT4, ly3, v2, pN3, cH1, stage IV). An immu- 


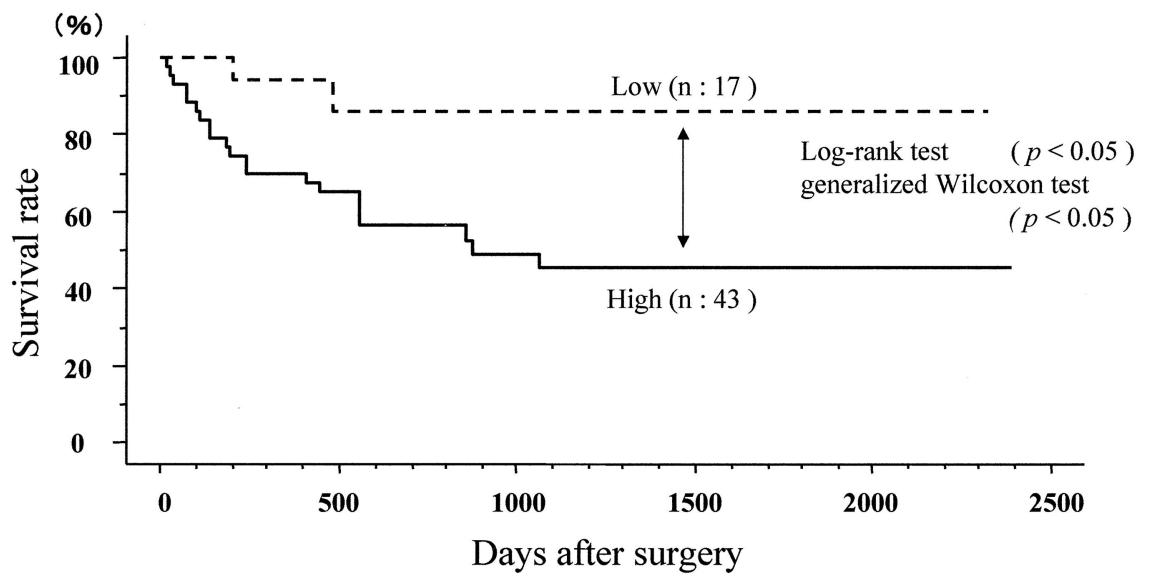

Fig. 7. Cumulative survival curves in patients with high or low serum values of IL-6 (Kaplan-Meier method)

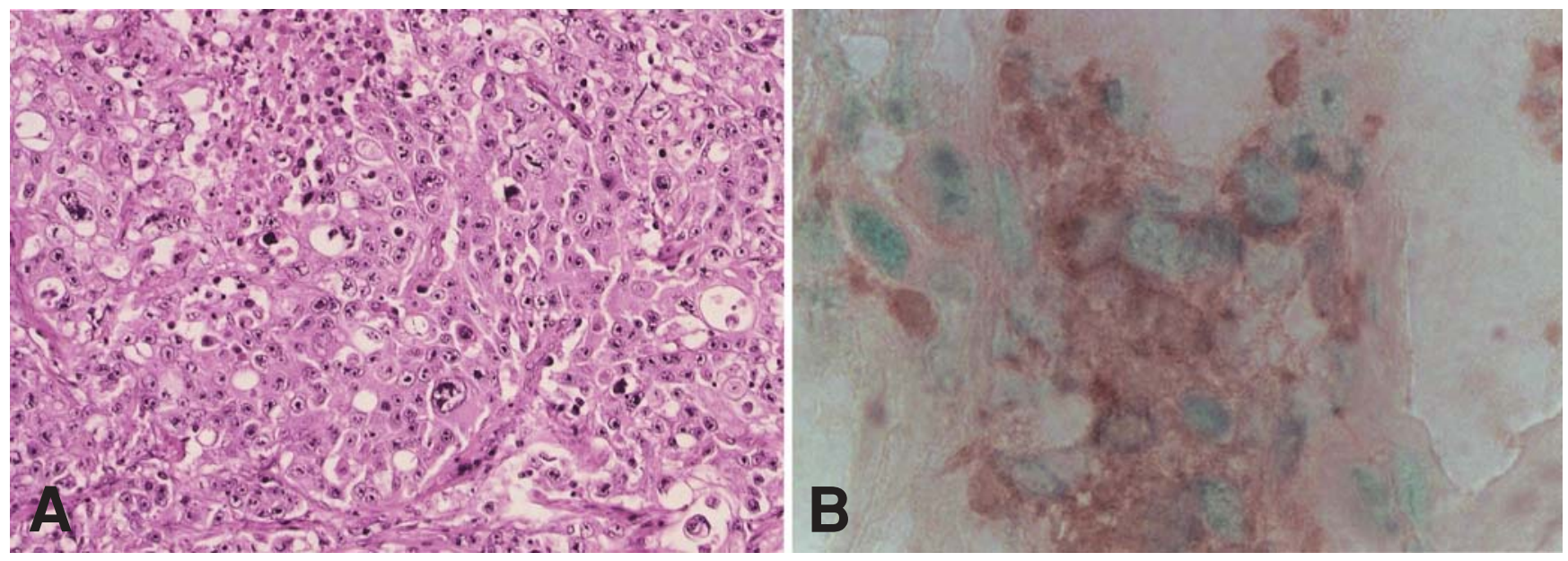

Fig. 8A,B. Microscopic findings. A The main tumor shows poorly differentiated adenocarcinoma. B Immunohistochemical study shows positive staining for IL-6 in the cytoplasm of the adenocarcinoma cells. A H\&E, $\times 200 ; \mathbf{B} \times 400$

nohistochemical study showed positive staining for IL-6 in the cytoplasm of the adenocarcinoma cells (Fig. 8B).

\section{Discussion}

In 1986, the deduced nucleotide and amino-acid sequences of cloned human IL-6 cDNA were purified. Human IL-6 consists of 212 amino acids, including a hydrophobic signal sequence of 28 amino acids [4-6]. On the other hand, the IL-6 receptor (IL-6R) system consists of an 80-kD glucoprotein (IL-6R) and a 130-kD glucoprotein (gp130), and signals are transferred into cells by IL- 6 combined with IL-6R on the cell membrane [7]. It has been found that IL-6 is produced by many different types of lymphoid and nonlymphoid cells. It is now also known that IL-6 is involved in the following multiple biological activities: (1) T-cell growth and differentiation; (2) IL-2 production and IL2 receptor expression in T cells; (3) B-cell growth and differentiation; (4) hematopoietic stem cell growth; (5) megakaryocyte maturation; (6) acute phase protein synthesis; (7) macrophage differentiation; (8) mesangial cell, keratinocyte, and osteoclast cell growth; (9) hybridoma, plasmacytoma, and myeloma growth; and (10) stimulation of cancer-cell growth [8-11]. We therefore considered "stimulation of cancer-cell growth by IL-6", and investigated the possible role of IL-6 in predicting the spread of tumors, including invasion and metastasis.

Cancer metastasis is a complex process involving coordinated cellular responses of both cancer cells and normal cells. The steps involved in metastasis are as follows: (1) invasion of the stroma; (2) intravasation of blood vessels; (3) circulation in the blood; (4) lodging and adhesion in target capillaries; (5) extravasation from the blood vessels; and (6) proliferation of secondary tumors [12]. IL-6 is thought to be involved in steps 1 , 2 , and 3 of the metastatic process.

As proof of the mechanism of IL- 6 action, Tamm et al. [13] showed that IL-6 makes cancer cells increase 
their motogenic activity, by autocrine pathway (IL-6 secreted from the cancer cells combines with the IL-6R, which is expressed on the surface of cancer cells, and together, IL- 6 and IL-6R act the cancer cells directly). It also became clear by subsequent research that a paracrine pathway was involved in the effects of HGF and IL- 6 on the invasion and metastasis of cancer cells [14-16]. When IL-6 produced by cancer cells stimulates interstitial cells to secrete HGF, HGF combines with the HGF receptor (c-Met) expressed on the cancer cells. HGF raises the motogenic activity of cancer cells, and it is thought that such cancer cells are then moved to the metastasis site. An association was seen between IL-6 and HGF in this research, and IL-6 may act through HGF on cancer cells, by the promotion and acceleration of invasion and lymph node and/or hepatic metastasis. In regard to the tumor, it is rational to say that IL-6 affects the environmental structure of the region in which metastasis tends to occur, not only acting on the cancer cells but also acting on the target organs, by the promotion of its action through HGF. It has been reported that intercellular adhesion molecule (ICAM)1, vascular cell adhesion molecule (VCAM)-1, and E-selectin are expressed on endothelial cells by proinflammatory cytokines such as IL- $1 \beta$ and TNF- $\alpha$, which are located upstream of IL-6 $[17,18]$, and which, combined with IL-6, promote the adhesion of cancer cells and endothelial cells [19]. However, IL-6 did not correlate significantly with IL- $1 \beta$ or TNF- $\alpha$ in this research. Because the ability of the measurement kits we used in the present study for IL- $\beta$ and TNF- $\alpha$ was inadequate measure very small quantities, the level measured in most patients (52 of 60 patients; $86.7 \%$ ) for IL-1 $\beta$, and 60 of 60 (100\%) patients for TNF- $\alpha$ ) was below the detection limit. Therefore, these two cytokines were compared in terms of marginal serum detection values (IL- $1 \beta, 10 \mathrm{pg} / \mathrm{ml}$; TNF- $\alpha, 5 \mathrm{pg} / \mathrm{ml}$ ) in these 112 patients.

Although specific IL-6 immunostaining was observed in the cytoplasm of cancer cells in patients with a very high IL-6 level (more than $15.0 \mathrm{pg} / \mathrm{ml}$ ), IL-6 immunostaining was not shown in patients with a low IL-6 level (less than $1.5 \mathrm{pg} / \mathrm{ml}$ ), strongly suggesting that a high serum level of IL-6 reflects IL-6 secretion by cancer cells. However, it remains unclear what upregulates IL-6 production in cancer cells.

Experimental studies have recently demonstrated that the in vitro treatment of Kupffer cells with carcinoembryonic antigen (CEA) induces the expression of cytokines such as IL- $1 \alpha$, IL- $1 \beta$, IL- 6 , and TNF- $\alpha$ [19]. In addition, the injection of CEA into mice resulted in a significant dose-dependent IL-6 response [20]. Furthermore, Belluco et al. [21] reported that the preoperative serum concentration of IL- 6 was associated with CEA in 208 patients with colorectal cancer.
These data suggest that CEA induces the systemic production of IL-6. However, there was no significant relationship between IL-6 and CEA in the present study (data not shown; $r \mathrm{~s}=0.1006$ ). The role of CEA in the upregulation of IL-6 in cancer cells is considered to be an important research subject, and such research would need to examine the relevance of IL- $1 \beta$ and TNF- $\alpha$, which are located upstream of IL-6. Further studies are needed to clarify the mechanism underlying IL-6 production and its effect in patients with gastric cancer.

Because IL- 6 is affected by various clinical conditions, such as sepsis, trauma, surgery, inflammation, and other forms of chronic stress, its serum level may reflect much indefinite bias, and it is therefore not necessarily suitable as a screening modality to rule out malignancy. Based on our results, the clinical significance of IL-6 is limited to evaluating the spread of gastric cancer, and it should be used as a tumor marker of advanced gastric cancer and lymph node metastasis. Actually, with regard to the diagnostic significance of IL-6 serum levels for advanced gastric cancer and lymph node metastasis, when the cutoff value of IL- 6 was set at $1.97 \mathrm{pg} / \mathrm{ml}$, the sensitivity was $81.8 \%$ and $87.5 \%$; specificity was $66.7 \%$ and $58.3 \%$; and accuracy was $77.1 \%$ and $72.9 \%$, respectively. Although it cannot be said that the specificity is high enough, the sensitivity and accuracy are high and are not inferior to those for other tumor markers, such as CEA and carbohydrate antigen (CA) 19-9 [22]. Moreover, we found that patients with a high serum level of IL-6 exhibited a significantly poor outcome compared with patients with a low level of IL-6. Therefore, serum IL-6 may be valuable as a prognostic factor for survival, and it is recommended for the preoperative prediction of disease stage. In patients with IL-6producing gastric cancer who show high levels of C-reactive protein (CRP) before operation [23,24], examination of the serum IL-6 level and IL-6 expression in cancer cells would be useful to estimate whether there is a high risk of lymph node and/or hepatic metastasis after surgical removal of the primary tumor.

Elevations of IL-6 levels can be seen temporarily after surgery, with the levels depending on the type of surgical intervention $[25,26]$. It is also well known that there are some cases of the spread of malignant tumor being accelerated after surgical treatment [27]. It cannot be denied that elevations of IL- 6 may be involved in accelerating the activity and spread of cancer cells. Therefore, if a curative operation cannot be performed, we should not perform unnecessary procedures for patients with far-advanced gastric cancer.

Acknowledgments The authors are indebted to Assistant Professor Raoul Breugelmans of the International Medical Communications Center of Tokyo Medical University for his review of this manuscript. 


\section{References}

1. Tahara E. Growth factors and oncogenes in human gastrointestinal carcinomas. J Cancer Res Clin Oncol 1990;116:121-31.

2. Egami H, Kamohara H, Mita S, Ogawa M. Involvement of cytokines in invasion and metastasis of colon cancer. J Jpn Surg Soc 1998;99:425-9.

3. Japanese Gastric Cancer Association. Japanese classification of gastric carcinoma. 13th ed. Tokyo: Kanehara; 1999.

4. Hirano T, Yasukawa K, Harada H, Taga T, Watanabe Y, Matsuda $\mathrm{T}$, et al. Complementary DNA for a novel human interleukin (BSF-2) that induces B lymphocytes to produce immunoglobulin. Nature 1986;324:73-6.

5. Zilberstein A, Ruggieri R, Korn JH, Revel M. Structure and expression of cDNA and genes for human interferon-beta-2, a distinct species inducible by growth-stimulatory cytokines. EMBO J 1986;5:2529-37.

6. Haegeman G, Content J, Volckaert G, Derynck R, Tavernier J, Fires W. Structural analysis of the sequence coding for an inducible 26-kDa protein in human fibroblasts. Eur J Biochem 1986; 159:625-32.

7. Hibi M, Murakami M, Saito M, Hirano T, Taga T, Kishimoto T. Molecular cloning and expression of an IL-6 signal transducer, gp130. Cell 1990;63:1149-57.

8. Hirano T, Kishimoto T. Interleukin-6. In: Sporn MB, editor. Handbook of experimental pharmacology, vol. 95. Berlin Heidelberg New York Tokyo: Springer-Verlag; 1990. p. 633-65.

9. Akira S, Taga T, Kishimoto T. Interleukin-6 in biology and medicine. Adv Immunol 1993;54:1-78.

10. Ueda T, Shimada E, Urakawa T. Serum levels of cytokines in patients with colorectal cancer: possible involvement of interleukin-6 and interleukin-8 in hematogenous metastasis. J Gastroenterol 1994;29:423-9.

11. Takeda K, Fujii N, Nitta Y, Sakihara H, Nakayama K, Rikiishi H, et al. Murine tumor cells metastasizing selectively in the liver: ability to produce hepatocyte-activating cytokines interleukin-1 and/or -6. Jpn J Cancer Res 1991;82:1299-308.

12. Fidler IJ. Selection of successive tumour lines for metastasis. Nat New Biol 1973;242:148-9.

13. Tamm I, Cardinale I, Sehgal PB. Interleukin-6 and 12-Otetradecanoyl-phorbol-13-acetate act synergistically in inducing cell-cell separation and migration of human breast carcinoma cells. Cytokine 1991;3:212-23.

14. Kitamura N, Miyazawa K, Uehara Y, Komada M, Okajima A, Okigaki M, et al. Gene expression and regulation of HGF-SF. EXS 1993;65:49-65.
15. Liu Y, Tolbert EM, Sun AM, Dworkin LD. Primary structure of rat $\mathrm{HGF}$ receptor and induced expression in glomerular mesangial cells. Am J Physiol 1996;27:F679-88.

16. Ashizawa T, Aoki T, Sumi T, Katsumata K, Tomioka H, Koyanagi $\mathrm{Y}$, et al. The study of hepatocyte growth factor (HGF) in the spreading of colorectal cancer. The clinical role of HGF in Dukes' classification. Jpn J Gastroenterol Surg 2002;35: 480-6.

17. Shalaby MR, Waage A, Aarden L, Espevik T. Endotoxin, tumor necrosis factor- $\alpha$ and interleukin 1 induce interleukin 6 production in vivo. Clin Immunol Immunopathol 1989;53:488-98.

18. Fong Y, Tracy KJ, Moldawer LL, Hesse DG, Monogue KB, Kenney JS, et al. Antibodies to cachectin/tumor necrosis factor reduce interleukin $1 \beta$ and interleukin 6 appearance during lethal bacteremia. J Exp Med 1989;170:1627-33.

19. Gangopadhyay A, Lazure DA, Thomas P. Adhesion of colorectal carcinoma cells to the endothelium is mediated by cytokines from CEA-stimulated Kupffer cells. Clin Exp Metastasis 1998;16:70312.

20. Edmiston KH, Gangopadhyay A, Shoji Y, Nachman AP, Thomas $\mathrm{P}$, Jessup JM. In vivo induction of murine cytokine production by carcinoembryonic antigen. Cancer Res 1997;57:4432-6.

21. Belluco C, Nitti D, Frantz M, Toppan P, Basso D, Plebani M, et al. Interleukin-6 blood level is associated with circulating carcinoembryonic antigen and prognosis in patients with colorectal cancer. Ann Surg Oncol 2000;7:133-8.

22. Takahashi Y. Gastrointestinal tract. In: Ookura H, editor. Tumor marker clinical manual. Tokyo: Igaku-shoin; 1999. p. 803.

23. Gauldie J, Richards C, Harnish D, Lansdorp P, Baumann H. Interferon $\beta_{2} / \mathrm{B}$-cell stimulatory factor type 2 shares identity with monocyte-derived hepatocyte-stimulating factor and regulates the major acute phase protein response in liver cells. Proc Natl Acad Sci USA 1987;84:7251-5.

24. Nijesten MWN, de Groot ER, ten Duis HJ, Klasen HJ, Hack CE, Aarden LA. Serum levels of interleukin-6 and acute phase responses. Lancet 1987;II:921.

25. Nishimoto N, Yoshizaki K, Tagoh H, Monden M, Kishimoto S, Hirano T, et al. Elevation of serum interleukin 6 prior to acute phase proteins on the inflammation by surgical operation. Clin Immunol Immunopathol 1989; 50: 399-401.

26. Egami H, Arakawa H, Sakamoto K, Ikei S, Ogawa M. The role of cytokines in surgical trauma. Geka Chiryo (Surg Ther) 1991;65: 149-55.

27. Hirai T, Yamashita Y, Mukaida H, Kuwahara M, Inoue H, Toge T. Poor prognosis in esophageal cancer patients with postoperative complications. Surg Today 1998;28:576-9. 